Journal of Language Teaching and Learning, Linguistics and Literature

ISSN 2338-4778 (Print)

ISSN 2548-4129 (Online)

Volume 7, Number 2, December 2019

pp. $72-86$

\title{
Teaching Speaking
}

\section{by Using Snake and Ladder Board Game}

\author{
Soleman Dapa Taka \\ sdapataka@gmail.com \\ Universitas Nusa Cendana, Kupang, NTT
}

Received : 3 September 2019; Accepted : 20 November 2019

\begin{abstract}
This research focuses on the use of the Snake and Ladder Board Game in teaching speaking to the tenth grade students at SMA Kristen Mercusuar Kupang. This research aims at finding out the appropriate way of teaching speaking by using snake and ladder board game for students in the tenth grade students at SMA Kristen Mercusuar Kupang.. This research used Classroom Action Research (CAR). The subject of the research is the tenth grade students at SMA Kristen Mercusuar Kupang.. The procedure of the research applied two cycles namely cycle I and cycle II. Every single cycle had fourth steps namely planning, implementing, observing and reflecting. The result of this research shown that there were significant developments on students speaking skill at the tenth grade students at SMA Kristen Mercusuar Kupang after conducting the treatments through snake and ladder board game. In which the score of a cycle 1 am 43,06 and the score of cycle II is 71,88 . It means that the snake and ladder board game is an appropriate way to improve the students speaking skills. In addition, the researcher found the result of the observation that almost all of the students gave positive responses, such as they gave attention seriously in learning process, they had been more active than before, make them happy and enjoy the class, and of course they could improve their speaking toward snake and ladder board game in improving speaking skill
\end{abstract}

Keywords: teaching speaking, snake and ladder board game

\section{Introduction}

Speaking skill is difficult for foreign learners because an effective oral communication requires the ability to use language appropriately in social interaction. However, since a language is used in social interaction, 
the learners of language must be good in speaking. Speaking depends on an understanding of what has been said by the speaker or the interlocutor. Teaching speaking is sometimes considered a simple process, commercial language schools around the world hire people with no training to teach conversation. Although speaking is natural, speaking in a language other than our own is anything but simple.

Speaking clearly and confidently can gain the attention of an audience, providing the golden opportunity for the speaker to make the message known. Speaking skill is important for carrier success, but certainly not limited to one's professional aspirations. Speaking skills can enhance one's personal life and thereby bring about the well-rounded growth that we should all seek. Speaking skills can help in all areas of life. Speaking is the most important and most dreaded form of communication. Speaking results in an increase in confidence and with that, a cool and collected presence in front of the audience.

Some people or learners studied English, encountered a problem on how to speak to other people well. It can be said that the learning process in school was an attempt by teachers to make students learn. Activities in class that do not make students learn can't be said to be a learning process. Based on the observation at the tenth grade students at SMA Kristen Mercusuar Kupang, the researcher found that students are lack of practice English, especially on speaking practice. So there are many students cannot speak English fluently. Students are speaking English based on the textual reading, they were bored during the learning process, and they seldom join in speaking class because they are afraid and also get shy in speaking.

Using games will help to increase student enthusiasm in the learning activity because there are many games involving the participation of students to be more active in learning activities. Application games method helping to improve the ability of students in English including speaking skills, because speaking is the basic key to communicate. Lack of practice may hamper the improvement of student's speaking skills. According to Rumbold which was quoted by Bennet said games is a powerful motivator, encourage children to be a creative and developing idea, comprehension and their language. It's mean through games children can commit, apply and test they know. The games are used as a medium of entertainment, but then much developed in the world of education. Games that can be used in learning are games that have been designed and tailored to the learning objectives. And in this research, the game the researcher takes is a snake and ladder game.

Snake and ladder board game is a fun game to do and it helps the students learn the language while playing in less anxiety. Using a snake and ladder board game will help to increase enthusiasm and interested student in teaching speaking. The aim of this game makes students the 
Sulaiman :

Teaching Speaking by Using Snake and Ladder Board Game

confidence to speak English and vanish their feeling about afraid to speak up. The students will speak using English with their friends to complete the task of the game clues. So, the students will study while playing a game through a snake and ladder board game.

Media is a tool for teaching that is used to stimulate the mind, feeling, attention and ability or skill of the learner can encourage the learning process. The use of media in the learning process can generate new desire and interest, generate motivation and stimulation of learning activities and even bring psychological influences to students. The researcher will use a card as a media for the learning process. The card is used to make the learning process more interesting and make students more active in the learning process.

Related to the background above, the researcher identified the problem: 1) Students speaking English based on the textual reading. 2) Student is bored during learning process. 3) Student seldom join in speaking class because they are afraid and also shy in saying. The researcher formulated a research question as follow: How is the appropriate way of using snake and ladder board game in teaching speaking for the tenth grade students at SMA Kristen Mercusuar Kupang.?

\section{Review of Related Literature}

\section{Speaking}

Speaking is important for language learners. Because of speaking we can make an understanding about information and circumstance in our environment. To make unifying the amity we need to communication. Because communication is the effective giving and receiving of information, to be effective the message must be understand by both the communicator and the receiver. Speaking is the process of conveying meaning from the speakers to the hearers through the use of verbal and non verbal symbol.

Speaking skill is always related to communication. Speaking skill can be stated as the skill to use the language accurately to express meanings in order to transfer or to get knowledge and information from other people in the whole life situation. Therefore, in order to be able to wage successfully fluent oral production the speaker must possess knowledge of the language and skill to use properly and precisely. Speaking is an interactive process of constructing meaning that involves producing and receiving and processing information. Speaking is the delivery of language through the mouth. To speak, we create sounds using many parts of our body, including the lungs, vocal tract, vocal chords, tongue, teeth, and lips.

Speaking is like any other skills, such as driving or playing a music instrument: the more practice you get, the more likely it is you will 
be able to chunk small units into large ones (Thornbury, 2005). Speaking clearly and effectively is essential if your organization's personnel are to be perceived as competent and confident in their daily activity. Speaking is the productive aural/oral skill. It consists of producing systematic verbal utterances to convey meaning (Nunan, 2003). Speaking as "a skill by which (they) people are judge while first expressions are being produced" (Hedge, 2000).

Speaking is one of the skills that have to be mastered by students in learning English. Speaking is an essential tool for communicating. For the teacher of English speaking, who are going to apply teaching speaking should be responsible to pay attention to some instructions to relate their teaching material to the real experience. So that the students can connect their speaking ability and experience in their daily.

Turk (2003) defines speaking as the direct route one mind another, and is the way we usually choose when we want to ask question, or give explanation. The information in more easily understood through speech that through writing. The speaker can express their idea easily because by using spoken language the speaker can use verbal or non verbal expressions to emphasis meaning. Harmer (2001) defines speaking ability to speak fluently presupposed not only knowledge of language features, but also the ability to process information and language "on the spot". It happens in the real situation and has little time for detailed planning. Therefore, the fluency is required to reach the goal of the conversation (Harmer, 1998). Based on the explanation experts above the researcher concluded that speaking is activity that we do to communicate with another people to get information.

Brown (2001) says spoken language is easy to perform, but in some cases it is difficult, in order that they can carry out the successful speaking, they must have some characteristics of successful speaking activities such as : (a). Learners talk a lot. As much as possible of the period of time allocated to the activity is in fact occupied by learners talk. This may be obvious, but often most time is taken up with teacher talk or pauses. (b). Motivation is high. Learners are eager to speak because they are interested in the topic and have something new to say about it, or they want to contribute to achieve a task objective. (c). Language is of an acceptable level. Learners express themselves in utterances that are relevant, easy comprehensible to each other and of acceptable level of language accuracy.

\section{Games}

Game is an activity that one engages for amusement or fun. Game is an activity or sport usually involving skill, knowledge or chance in which you follow fixed rules and try to win against an opponent or to solve a puzzle. Game is one of method to improving ability students. The use of games in a 
learning environment will not only change the dynamic of the class, but it will also rejuvenate students and help the brain to learn more effectively. Incorporating games in the classroom can increase students learning experience, make materials more current and relevant. Games provide the students with new and varied learning environments that meet learners learning style.

The more exciting and interactive a teacher can make the learning environment, the more a teacher tries to introduce games and activities (Agoestyawati, 2007) Games are highly motivating because they are amusing and interesting (Erzos, 2005). Game is an activity or a sport with rules in which people or teams compete against each other (Horby, 2006). Games automatically stimulate the students interest and properly introduced game can be one of the highest motivating tehniques. And one significant different between language games and other activities is that they

introduce an element of competition into the lesson (Mc Callum, 1980) Games make learners more willing to ask questions and think creatively about how to use English to achieve the goal (Chen I Jung, 2005)

Based on the explanation experts above the researcher concluded game is an activity that give motivation and interested to students in learning process, because game will increase concentration and students will more active in learning.

Advantages of playing game in the classroom are (a). more motivation (b). Controlled competitiveness (c). Strategy simulator (d). Peer positivity (e). Smaller stress (f). Mighty memory (g). Class cooperation (h). Alert attention (i). Friendly fun (j). New knowledge. Then, Carrier (2001) states that the advantages of using games can be summarized as follows: (a). Games add variety to range of learning situations (b). Games can minting motivation (c). Games can refresh learners during formal learning (d). Games can encourage an interest of those students whole feel intimidated by formal classroom situations (e). Games can make a teacher-student distance less marginal (f). Games give an opportunity for students communication and can reduce more usual student-teacher communication (g). Games can act as a testing mechanism, in the sense that they will expose areas of weakness.

In addition, Carrier (2001) Classifying games into categories can be difficult, because categories often overlap. Hadfield explains two ways of classifying language games. The first, she divides language games into two types: linguistic games and communicative games. Linguistic games focus on accuracy, such as supplying the correct antonym. On the other hand, communicative games focus on successful exchange of information and ideas, such as two people identifying the differences between their two pictures which are similar to one another but not exactly alike. Correct language usage, 
though still important is secondary to achieving the communicative goal.

\section{Snake and Ladder Board Game}

Board game is a kind of game that can be applied in language teaching as Porenzo (1981) said that board game has also been used to teach children basic fact and information about the world in which they live. In the board game the materials that are needed include counters, dice, game board, and clue cards. There are many type of board game such as monopoly, snakes and ladders, ludo etc. Snakes and ladder is a board game for kids that is played by two or more people. Snake and ladder board game is a board game in which pictures of snakes and ladders retard or facilitate the players' progress. snake and ladder game is a board game in which players move counter along a series of squares according to throws of a dice. a ladder provides a short cut to a square nearer the finish and a snake obliges a player to return to a square nearer the start.

According to Rodilla (2012) some benefits of using board games for learners are providing rich learning opportunities and improving their learning ways, connecting to real life situations, encoring the use of authentic materials and guarantee fresh content. According to Muaddab as cited in Nachiappan(2014) snakes and ladder game was created in the $2^{\text {nd }}$ century BC developed by the Hindus to teach their children of morality lesson. The game named "Paramapada Sopanam" or Ladder to Salvation. The ladders provide a short to a square nearer the finish square and the snakes obligate the players to return to a square nearer the start square. The snakes symbolize bad omens and the ladders represented good values. The game has become part of the traditional game in Indonesia although there is no detailed information about its commencement in Indonesia. This game can also be used as a tool to teach, entertain, and to build up interactive communication among the players (Bayuningsih, 2016).

The game board is divided into small boxes and in some boxes is drawn a number of "ladder" or "snake" that connect it to another box. This game was created in 1870. Each player stars with a piece in the first box (usually the box in the lower left corner) and takes turns throwing the dice. The pawn is run according to the number of dice eyes that appear. If the player lands at the bottom of a ladder, they can immediately go to the other end of the stairs. When landing in a box at the bottom end of the snake. The winner is the first player to reach the last box. Usually when a player gets 6 from the dice, they get a turn once more, if not then turn to the next player.

The benefits snake and ladder board game: (1). Provide knowledge to children through the learning process of playing while learning. (2). Stimulates developing thinking, creativity, and language so as to be able to 
foster good attitude, mentality and morals. (3). Creating an attractive playing environment, providing a sense of security and sun. (4). Know losing and winning (5). Learn to work together and wait for their turn. Then, some benefits of using board games for learners (1). Providing rich learning opportunities. (2). Improving their learning ways (3). Connecting to real life situations (4). Encoring the use of authentic materials (5). Guarantee fresh content (Fathhan, 2019)

Some benefits using board game for teacher (1). Helping teacher get learners involved (2). Get a more positive and proactive response (3). Enhancing students motivation (4). Providing endless possibilities and kinds of material (5). Improve teacher's teaching practice (6). Encourage teachers to put aside the text book and usual teaching practices temporarily (Radilla, 2012).

Then, the rocedure of using snake and ladder board game (1) First place a snake and ladder board game in a table or on the floor (which ever you feel comfortable) and sit around it (2) Decide who will go first and who will go last and pick a different colored counter for each person (3) Place all the counters on the side of the board and player 1 can roll their dices, they can only start if they get either 6 on either dice (4) If you don't get either 6 its next players turn to roll the dice (5) Keep rolling the dice until you get 6 . Once you get either one count the two numbers on your dice and move according to the number (6) Keep adding on after each turn you have. Follow the numbers as you go along (7) If you land on a ladder go up (8) If you land on a snakes tail go down (9) The first one finished the game is the winner.

\section{Method}

The method applied in this research was CAR (Classroom Action Research). It was used to discover the appropriate way in improving the quality of English teachers' performance in instruction as well as students' achievement in learning English in classroom. In classroom action research, English teachers assess the effectiveness of their own teaching activities and plan the improvement based on the result of the assessment. Classroom Action Research was the research conducted by the classroom teacher or school where teaching with emphases in the improvement or enhancement of learning practices and processes. In order to solve the problem, the researcher use CAR (Classroom Action Research) that contains of four stages: they are planning, implementation of action, observation and reflection.

The research begun with surveying and identifying classroom problems. A classroom problems pointing to the classroom practice that will be improved to result in a better learning achievements of the students. Based on the result of observation that is done by the researcher, most of students were still less of speaking. That is why the design of this research refers to 
planning of how to teaching speaking well. It is expected that the planning can increase the students' mastery in English speaking. The researcher made a planning with the collaborator about the strategy on speaking learning, and the researcher was focus on classroom action research in teaching speaking in using Snake and Ladder Board Game. The subject of this research was the tenth grade students at SMA Kristen Mercusuar Kupang with different ability backgrounds starting from the high, medium and low seen from the intelligence and intellectuals of each student. from 25 students consisting of 10 men and 15 women.

The position of students in this research as subject of the research, the researcher hope after researching the students can improve their speaking. The position of collaborator in this research as a observer, the collaborator help the researcher to observe the students, so the researcher is able to know the students condition in learning process and give su ggestion and solution to the problem for each cycle. In the cycle 1, there were four stages namely : planning, implementation, observation and reflection. In the Second Cycle, there were also four stages namely : planning, implementation, observation and reflection.

In this research there were two kinds of observation, observations students' activity and observation implementation of learning. Observation students 'activity was focused on students active in learning process and observation implementation of learning was focused on teacher activity or students active in learning process. Observation was conducted by the written way or spoken way. Speaking test was used to obtain the information about the students' speaking skills before and after the implementation of snake and ladder board game in teaching and learning process of speaking. The test was done twice, in the forms of pre-test and post-test. The researcher used some picture in test, and the students make description based on the picture. The researcher used speaking rubrics to collect the sources of the students' speaking performance and analyzed the fluency, accuracy, and comprehensibility. The researcher used camera as instrument to collecting data to take a record in the process of teaching learning speaking as an evidence this research. The data from speaking test was the score on the scoring classification. They were Fluency, Accuracy and Comprehensibility.

\section{Results}

\section{Condition of the class}

The researcher got some data about the condition of the class which were problems for students. The researcher was informed that condition of students in the class was the lack of practice English especially on speaking practice. So 
there were many students did not speaking English fluently. Some students spoke based on the textual reading. Then some students were bored during learning process and also seldom joined in speaking class. The researcher knew the students ability based on the result of pre-test, where the researcher gave students picture, then the students choose one picture and then describe based on the picture. After the researcher gave pre -test then the researcher toll students the purpose of the test.

\section{Cycle 1}

a) Planning

In the planning section of this cycle, the researcher prepared all tools that needed to carry out the study in the class, such as lesson plan, preparing the test to knew the basic students' speaking ability, the researcher also prepared some tools as the instrument to support this research such as snake and ladder board game, observation sheets and camera. a) The researcher welcomed the students b) The researcher explained speaking material and the ruled of snake and ladder board game c) The researcher informed about learning activities for the next meeting $\mathrm{d}$ ) The researcher finished learning activity by pray together

\section{2) Implementing}

In first cycle the researcher started on Wednesday 17 July 2019 at 9.00 am. The researcher and collaborator entered to the English class. He said greeting and asking the students about their condition and pray together to start the lesson. The researcher prepared tools that would be used to learn. And then the researcher asked to students about condition to be ready to study and prepare the teaching. The researcher explained the procedure of learning before the researcher starting the lesson. Before explaining about the material the researcher asked the students and said "do you know how to describe people" then the students said "No. I don't know". The researcher told the students about the material and told about the game that will be used. After that the researcher explained how to use and the rules how to play snake and ladder board game to improve their speaking. The students can ask researcher if they confused or did not understand with the material that researcher gave before. Then the researcher gave chance to students one by one to come forward in front of class to present the material individually that the researcher had explained previously. It was conducted when the researcher was sure all of the students had already understood about the material 
The researcher then divided students into five groups. The researcher divided them by asking the students to count. Each student counted beginning from 1 until 5 and back again to 1 until 5 again and so on, for example a student count 1 , the next student said 2 , the next students said 3 , next student said 4 and the next student said 5 and next student back again said 1 and so on until all of the students get number, after that the researcher ask them to collect each number, for example each number 1 collect with number 1 , number 2 collect with number 2 , number 3 collect with number 3 , number 4 collect with number 4 and number 5 collect with number 5 . Each group consists of 5 members. After making group then the students started to play the game that the researcher toll before. The end of this meeting the researcher gave conclusion about the material, then the researcher toll the students' word or sentence that they did not before. Than the researcher toll about the material in the next meeting, after that the researcher closed the meeting.

\section{3) Observing}

Based on the result of observing in first cycle the researcher found some problems in teaching learning process. When the researcher gave speaking material in the class there were students did not pay attention, they were disturb each other. Then the researcher tries to make normally the situation in the class, it was make students quite situation and the researcher continued the material. But for the several minutes later the students made crowded in class again.

In this cycle was not really conducive the students were very crowded. They spoke aloud to each other during the teaching learning process. There were students who did not understand about the rule of the game. The instruction should be repeated several times since it was the first time for the students played the game in the class.

4) Reflecting

The researcher and collaborator made reflecting to decrease the lack in this cycle. There was still significant weakness in the cycle I. When the researcher entered to the class some of students still busy with their activity but some of them also gave enthusiasm when the researcher and collaborator came to the class. Some of students were not really active in learning activities, only 5 students were very active, 7 students were active, 7 students were less active and 6 students were not active. It means that the students were not really active. In learning process there were students enjoyed because the researcher teaching material using game. So the students did not bore in learning process. The evaluation mean score only 43,06 . The advisement of the students still low. There were only some students were active in giving responding the topic that given by researcher.

In the fact after making observation the researcher concluded that the learning process that occurs in the classroom was relatively ineffective. $68 \%$ of 
students did not pay attention and followed the learning process optimally. They were disturbing each others. When they spoke English they were shy with their friends and if they making mistakes. The researcher was changed the learning model. In first cycle she asked the students to present a material individually. Because some of students shy if present the material individually. In the second cycle the researcher asked the students to choose a partner and discuss about the matererial that researcher gave before. After the class, the researcher gave students a material to learn at home to prepare in cycle II.

Based on the result of the observation, the students' score of the test were still disappointing in the first cycle. Therefore the researcher need to do reflection to identify the weakness action in cycle I they were: 1) the mean score the result of the students test in cycle I was 43,06. It means the score was still low. so the students score of the students in cycle II must be improved. 2) Based on the result the observation, the student's ability in speaking skill by snake and ladder board game were still low. Related to the students ability in speaking skill, the solution of problems would be prepared such as: 1) the researcher explained more material 2) the researcher formed the students in partner to discussing the material 3) the researcher guided the students more intense in material

\section{Cycle II}

a) Planning

The researcher hoped in cycle II the students were more active in class then before. The researcher and collaborator back to prepare all the requirement to continue the research such as: lesson plan (RPP), observation sheets, snake and ladder board game, camera and all of tools that researcher needed in this research. Planning in the second cycle is different with first cycle. In the second cycle to make students to be active in the class. The students will discuss the material with their partner and asking the researcher if they were confused the material. a) The researcher greeting to students $b$ ) Explain speaking material and the rule of snake and ladder board game c) finished learning activity by pray together

\section{2) Implementing}

In the second cycle the researcher started on Wednesday 07 August 2019, the researcher and collaborator entered to the English class. She said greeting and asking the students about their condition and pray together to start the lesson. The researcher explained the procedure of learning for this meeting before the researcher star the lesson.

The researcher toll the students about the material and game that used after that the researcher explained about speaking material and explained how to used and ruled to play snake and ladder board game to improve their speaking. The students can ask researcher if they confused with the material. Then the researcher gave chance to students come forward in front 
of class to present the material with their partner that their choose. When the researcher was sure all of the students understood about the material. The researcher divided students to be 5 groups. The researcher divided them by asking the students to count. Each student count beginning from 1 until 5 and back again to 1 until 5 again and so on, for example a student count 1 , the next student said 2, the next students said 3 , next student said 4 and the next student said 5 and next student back again said 1 and so on until all of the students get number, after that the researcher ask them to collect each number, for example each number 1 collect with number 1 , number 2 collect with number 2 , number 3 collect with number 3 , number 4 collect with number 4 and number 5 collect with number 5 . Each group consists of 5 members. The end of this meeting the researcher gave conclusion about the material, the researcher toll the students word or sentence that they did not before. After that the researcher closed the meeting and the researcher said "Thank you so much because you all ready to help me in my research".

\section{3) Observing}

Based on the result of observation in cycle II when the researcher gave speaking material in the class situation was conducive and did not crowd than before cycle. They could focus in learning process and the students did not disturb each other. The researcher tries to ice breaking in the class and made normally the crowded situation in class. So, the researcher could continue the material. In this cycle the students more active and could understand about the material and the rule of the game. And the researcher did not to repeat several times to give instruction to students.

\section{4) Reflecting}

The result of the last cycle the researcher and collaborator found the students really active and enjoy in lesson at the classroom. When the researcher entered to the class the students gave good enthusiasm when the researcher and collaborator came to the class. There were students active in learning activities, there were 13 students very active, 10 students were active, 2 students were less active and none students were not active. It means that the students were really active. In learning process there were students enjoyed because the researcher teaching material using game. So the students did not bored in learning process. The evaluation mean score was 71,88 . There were improved of the students score.

In the fact after making observation the researcher concluded that the learning process that occurs in the classroom was relatively effective. $98 \%$ of students gave pay attention and followed the learning process optimally. They did not disturb each others. The researcher explained about the material fluently without trouble in the class and they were very active to join the learning process. They had strong spirit, good participant and they will focus if 
the researcher gave explanation about the material. The researcher was changed the learning model. In first cycle she asked the students to present a material individually. Because some of students were shy if they presentedthe material individually. In this cycle the researcher asked the students to choose a partner and discuss about the material that researcher gave before.

Based on the result of the observation, the students' score of the test in cycle 2 were increase then in the cycle 1 . The mean score of cycle I was 43,06 and the mean score of cycle II was 71,88 . It was means the researcher and collaborator can conclude that in the second cycle the use of snake and ladder board game was appropriate way in teaching speaking.

There was great progress in the research to teaching speaking used snake and ladder board game in the learning process. Using snake and ladder board game made students more active, interesting and did not bored in learning process. It was repeatedly for two times from cycle I and cycle II.

The classroom action research had conducted in two cycles that consist of two meetings. Cycle I consisted of two meetings and cycle II consisted of two meetings. There were four stages: planning, implementing, observing and reflecting. The researcher's collaborator acted as the observer who observation and keep monitoring. During the research, observation the research process while the researcher apply the snake and ladder board game in the classroom based on the planning which has design by the researcher and collaborator.

However, after the students learning speaking through snake and ladder board game they feel enjoy and active in learning process. It can be seen from their enthusiastic and interested in the lesson while teaching learning process and the increase of their understanding from their score.

Based on the result of the students' speaking score, it was found that the students' speaking score was improving. It indicated that the use of snake and ladder board game could increase their speaking. Most of students gained good score at the end of cycle. The in the first cycle was 43,06 and the students' score in the second cycle was 71,88. In the first cycle was less success because the students' performance in classroom was less active to join learning process. Snake and ladder board game was great to use in teaching speaking and great ways too. Even thought, there were some students were active in this cycle. The result of score in cycle I the highest score was 61 and the lowest was 33, the mean score of the students was 43,06 . The researcher and collaborator has initiative to continue the research to more prove the power of snake and ladder board game but using different model from cycle $\mathrm{I}$.

In the second cycle made students to be active in the class. Almost students focused during the learning process. There were not shy to talk. From the result of the students speaking test the highest score was 83 and the 
lowest was 61. It mean the students result was improve. All of students has good participant in learning process and it cause the improvement of comprehension. The researcher and collaborator more believe that snake and ladder board game was really great in teaching students speaking ability and it really nice if we use in the classroom because the students will active and enjoy the lesson. The researcher takes some students as the representative who has different ability. The first student is student (04), the researcher found the student difficulty to describe. After the researcher gave explanation and applying snake and ladder board game in learning process, the students more interest to describe.. The second student is student (07). the researcher found the student low in fluency and accuracy in describe material. After the researcher gave explanation and applying snake and ladder board game in learning process, the students really enjoy in learning process.. and the last student is student (08), the researcher found that student low in comprehensibility in describe material. After the researcher gave explanation and applying snake and ladder board game in learning process, the student were more active in learning process.

This research are similar to Agnes Ambar Pratiwi Bayuningsih's study, where she said that the implementation of snakes and ladders board game was successfully done in improving the students' speaking ability. The game was effective because it gave fun atmosphere in learning and gave the students new experience in learning process. Endang Kusrini's study where she said that snake and ladder board game is more effective than translation in teaching vocabulary for the eighth grade of junior high school.

\section{Conclusion}

Based on the research result the researcher concluded the appropriate ways of teaching speaking through snake and ladder board game in the tenth grade students at SMA Kristen Mercusuar Kupang are: 1) the teacher prepares all tools that needed. 2) The teacher explained about the speaking material. 3) The teacher gives chance to students to explain the material with their partner. 4) The teacher explains about the game and the rule of the game that will use. 5) The teacher divides students into some group and begin to play the game. 6) The teacher comes to each group to check the students and gives help to students if they want. 7) For elementary learner the teacher gives more attention and gives guided more so that the student will not feel difficult in learning. 8) The teacher gives explanation and conclusion about the material.

\section{References}

Agoestyowati, Redjeki. (2007) 102 English Games Jakarta: PT. Gramedia Pustaka Utama 
Teaching Speaking by Using Snake and Ladder Board Game

Ambar Agnes Pratiwi Bayuningsih, “Improving students' speaking ability using the snakes and ladders board game at $11^{\text {th }}$ grade of SAINT PIUS $X$ Vocational high school Magelang"

Brown. (2001). Characteristic of successful speaking activities.. New York: Cambridge University Press.

Brown,H.D.(2000). Principles of Language Learning and Teaching. $4^{\text {th }}$ ed. New York : Longman.

Carrier, Michael and The Centre for British Teachers( 2001). Take 5 game and activities for the language learners. Nelson and sons Ltd, 1985. ISBN 0-17-444199-1

Chen, I-Jung. (2005) Using Games to Promote Communicative Skill in Language Learning. The Internet TESL Journal, XI (2),1-4.

Erzos Aydan (2005). Six games for EFL/ESL Classroom. The Internet TESL Journal, Vol. 6 No. 6

Fatkhan, Pengertian Media Pembelajaran Permainan Ular Tangga. In_http://fatkhan.web.id/pengertian-media-pembelajaran-permainanular- tangga/

Hadfield Jill, Elementary Vocabulary Games, online :http://www.google.com.Accesed on December $15^{\text {th }} 2018$.

Hedge, T. (2000). Teaching and Learning in the Language Classroom: Oxford Handbooks for Language Teachers. Oxford, U.K: Oxford University Press.p.261

Hornby (2006). Oxford Advance Learner's Dictionary. Seventh Edition. New York: Oxford University Press.

J.B.Heaton (1988) Writing English Language Test. New York: Longman Group UK, Company.

Kusrini Endang (2008) "Teaching vocabulary for junior high school students using snake and ladder game" Jurnal Aktif V.XIX, No 4

Mohammad Adnan Latief (2014), Research Methods on Language Learning: An Introduction. Malang: UM Press

Nunan, David (2003), Practical English Language Teaching,(first Edition) Singapore: McGraw Hill.

P. McCallum and P. George (1980). 101 Games. London: Oxford University Press

Rodilla, R.H.M. (2012) Playful Learning in the EFL Class: The Benefical of

Board Games and the LEGO Serious Play Method. Retrieved December 1,2018

Susilo (2009), Penelitian Tindakan Kelas, (Cet.II) Yogyakarta: Pustaka Book 
IDEAS, Vol. 7, No. 2, December 2019

ISSN 2338-4778 (Print) ISSN 2548-4192 (Online)

Publisher

Thornbury, Scott (2005), How to Teach Speaking, England: Pearson Education Limited

Trigon (1993) Pengajaran Kosakata, Cet. I; Bandung; Ankara 